\title{
Research Note: The Code of Regulations for the First U.S. Naval Hospital, Norfolk, Virginia, 1838
}

\section{James Alsop}

Dr. Thomas Williamson du Maryland, chirurgien de la marine des ÉtatsUnis, a écrit le premier code de conduite complet pour la premier hôpital construit expressément pour la marine à Norfolk, en Virginie. Williamson, un réformateur de la marine, était le fonctionnaire avec le plus d'influence sur l'hôpital au cours du premier quart de siècle de l'existence de ce dernier. Son code révèle ses attitudes à l'égard des marins, l'hygiène médicale, et la lutte pour la reconnaissance par le corps médical dans la marine d'avant guerre.

The Naval Hospital at Norfolk, Virginia, was the first permanent naval hospital in the United States. The long delays in establishing dedicated facilities to supersede the general-purpose marine hospitals and the temporary facilities in the U.S. naval yards are well known. ${ }^{1}$ Early centralized planning immediately prior to the War of 1812 designed to erect a series of purpose-built hospitals at the principal ports of the nation was stillborn. The result was decades of reliance upon facilities deemed to be inadequate. The hospital at the Gosport Navy Yard in 1815 was described by its surgeon as wholly unsuitable, being merely the second floor of a rotting frame building, sixty feet by thirtysix feet. It was sandwiched between the gunner's store room on the first floor, and the boatswain's department on the third. The noise level was appalling for the sick, and the space was impossible to heat in winter. ${ }^{2}$ In 1821 the Commissioners for the Navy Hospital Fund finally began to purchase sites for naval hospitals, first at Washington, D.C., and subsequently at Boston, Brooklyn, Philadelphia, and, in 1827, at Norfolk. ${ }^{3}$ On 2 April 1827 the cornerstone was laid for a Norfolk hospital capable of accommodating between three and five hundred patients. The institution opened in August 1830 in an unfinished state due to the depletion of the Hospital Fund; construction was resumed in late 1831 and continued over succeeding years. ${ }^{4}$ The Philadelphia Naval Asylum opened

1 H.A. Brings, "Naval Medicine Comes Ashore: Establishing the First Permanent U.S. Naval Hospitals," Journal of the History of Medicine and Allied Sciences 41 (1986), 257-92.

2 Surgeon Joseph Schoolfield to Commodore John Rodgers, 8 May 1815, National Archives and Records Administration (hereafter NARA), Department of the Navy, RG 45, Entry 464/205 (unnumbered).

3 Brings, 284-5.

4 R.C. Holcomb, A Century with Norfolk Naval Hospital, 1830-1930 (Portsmouth, VA.:

The Northern Mariner/le marin du nord, XXI No. 1, (January 2011), 60-67 
in 1832, followed only later by other regional naval hospitals at Boston, Brooklyn, and Pensacola on the model of the Norfolk institution. In the early years Norfolk remained pre-eminent, as a consequence both of its early construction and its convenience for numerous squadrons upon return from service in the Mediterranean, West Indies, South Atlantic, and Pacific.

The decade of the 1830s was one of growth and experimentation at the Norfolk hospital. Responsibility for initiatives fell principally upon the hospital surgeon. Norfolk possessed two distinguished surgeons in this decade, William P.C. Barton and Thomas Williamson. The former was surgeon for less than one year, beginning on 2 September 1830 , but by force of personality his administration had a lasting impact. His influence continued later, from a distance, when he served as Chief of the Bureau of Medicine and Surgery for the U.S. Navy, 1842-44. ${ }^{5}$ Williamson's role is at present far less well known, but considerably more influential. Hitherto, the historical profile of this practitioner and administrator has been non-existent. Williamson entered the wartime Navy in May 1813 as a surgeon's mate. He later served as an assistant surgeon in the West Indian squadron before being promoted to the rank of surgeon in March 1818. In 1823 he was appointed surgeon to the temporary naval hospital created in that year at Key West to deal with the serious health consequences of the campaign against Caribbean piracy. ${ }^{6}$ By 1826 he was surgeon to the Naval Yard at Gosport, Virginia. In that year the Commissioners of the Naval Hospital Fund delegated to Williamson and the distinguished Philadelphia naval surgeon, Dr. Thomas Harris, responsibility for selecting a site for the new hospital in the vicinity of Norfolk. ${ }^{7}$ On 30 January 1827 Williamson applied for the position of surgeon to the as yet unbuilt, institution, a request renewed in May $1829 .{ }^{8}$ He was first appointed as surgeon-in-charge in July 1830, although he departed on the following 23 August, having been ordered to sea duty. Williamson returned as surgeon from 11 May 1831 to 12 December 1839,5 May 1842 to 1 November 1847 , and 15 April 1852 to 5 July $1855 .{ }^{9}$ During the intervals away from Norfolk he refreshed his practice and experience through

Printcraft, 1930), 137-60. Construction records are in NARA, RG 45, Entry 464/498, 542, 545.

5 Holcomb, pp. 164-76, 224-6. Barton's career is sketched in F.L. Pleadwell, "William Paul Crillon Barton, Surgeon United States Navy. A Pioneer in American Naval Medicine (17861856)," Annals of Medical History 2 (1919), 264-301.

6 W.P.C. Barton, A Treatise Containing a Plan for the Internal Organization and Government of Marine Hospitals in the United States (Philadelphia: the author, 1814), 244; NARA, RG 45, Entry 464/216 (5 February 1840); A.W. Diddle, "Medical Events in the History of Key West, I. The Marine Hospital," Bulletin of the History of Medicine 15 (1944), 445-7; A.G. Foraker, "The United States Marine Hospital, Key West, 1845-1943," Journal of the Florida Medical Association 59 (1972), 37; Navy Register of the United States for the Year 1832 (Washington: Blair, 1832), 30.

7 Holcomb, pp. 51-2. For Harris, see L.H. Roddis, "Thomas Harris, M.D., Naval Surgeon and Founder of the First School of Naval Medicine in the New World," Journal of the History of Medicine and Allied Sciences 5 (1958), 236-50.

8 Holcomb, 161-2.

9 Ibid., 163-4, 516. 
active sea service; in 1840-42, for example, Williamson was fleet surgeon to the Mediterranean squadron. ${ }^{10}$ In 1855, Napoleon III, Emperor of France, awarded Williamson a gold medal for his actions in treating the victims of the yellow fever epidemic aboard the French steamer-of-war, La Chimère, at Norfolk Hospital in 1854. ${ }^{11}$

Little evidence hitherto has come to light for the early medical practice and administration at the Norfolk hospital. ${ }^{12}$ Documents in the National Archives shed important light upon some aspects during the first decade of operation under the jurisdiction of Dr. Williamson. In particular, the previously unknown code of governance established by Williamson in July 1838 at the request of the secretary of the navy, James Paulding, is worthy of notice. As the first set of regulations in use within the new naval hospitals, it had pride of place in the Navy. The regulations were not created in a vacuum. Much had been written on the ideal administration of naval hospitals in the United States during the long gestation from planning, which had begun as early as 1811, to construction. ${ }^{13}$ However, Williamson's code, printed below, reveals, for the first time, the actual code of practice created by a senior surgeon with previous experience in leading two hospitals for the U.S. Navy, and clearly influenced by the on-going expansion and developments at Norfolk up to 1838.

In establishing the context for the code of governance, several observations are in order. First, the Norfolk institution during the 1830s existed within a peacetime naval establishment where medical care for personnel can be characterized by reference to three categories of affliction: minor, chronic, and episodic. One of the urgent requirements filled by Norfolk, as the first permanent facility, was as a home for the long-term, chronic sick. A second was as a place for treatment and recuperation of servicemen in the homecoming squadrons, whose immediate needs could, and did, overwhelm the fairly modest Norfolk infrastructure for short, intense, periods. The hospital, therefore, had to balance the ever-present demands for economy and efficiency with its on-going principal role, and to create the flexibility needed to respond to unpredictable crises. Dr. Barton emphasized his accomplishments to his superiors by implementing at Norfolk a regime dedicated to strict economy. ${ }^{14}$ This proved to be insupportable in the long term. Even in peacetime, there existed a steady upward pressure on admissions. Prior to the opening of the Norfolk institution, the Navy admitted for treatment an average of approximately 139 personnel into the existing Virginia medical facilities each year. ${ }^{15}$ One decade later,

10 Thomas Williamson to James Paulding, Secretary of the Navy, 5, 8, and 10 February 1840, NARA, RG 45, Entry 464/216.

11 Holcomb, 426-8.

12 Ibid., chapters VI, VIII.

13 U.S. Congress, The Public Statutes at Large of the United States of America, R. Peters, ed., 8 vols. (Boston: Little and Brown, 1845-6), II: 650-51; Barton, passim; H. Langley, A History of Medicine in the Early U.S. Navy (Baltimore: Johns Hopkins, 1995), 171-3; Dr. George Davis to Paul Hamilton, 12 March 1811, and Dr. George Bates to Paul Hamilton, 14 January 1812, NARA, RG 45, Entry 464/206.

14 Holcomb, 164-76; Langley, 321; Barton to [John Branch], 15 November and 7 December 1830, 7 March 1831, NARA, RG 45, Entry 464/205.

15 U.S. Congress, American State Papers: Naval Affairs, 4 vols. (Washington: Gales and 
during the period immediately surrounding the Williamson regulations of July 1838 , Norfolk's quarterly medical statistics were as follows: ${ }^{16}$

\begin{tabular}{|l|r|r|r|r|r|}
\hline & \multicolumn{1}{|c|}{$\begin{array}{c}\text { July-Sept } \\
1837\end{array}$} & \multicolumn{1}{c|}{$\begin{array}{c}\text { Oct- Dec } \\
1837\end{array}$} & $\begin{array}{c}\text { Jan-Mar } \\
1838\end{array}$ & $\begin{array}{c}\text { Apr-June } \\
1838\end{array}$ & $\begin{array}{c}\text { July-Sept } \\
1838\end{array}$ \\
\hline Sick list at start of quarter & 67 & 45 & 29 & 60 & 35 \\
\hline Admitted & 109 & 41 & 96 & 75 & 51 \\
\hline Discharged & 116 & 54 & 63 & 97 & 58 \\
\hline Died & 10 & 3 & 2 & 3 & 2 \\
\hline Remaining in hospital & 45 & 29 & 60 & 35 & 26 \\
\hline
\end{tabular}

These records reveal variable new admissions, as high as 320 a year, upon a steady base of the long-term chronic ill. The strain was often apparent. Even the preparations for the departure of a single ship, such as the dispatch of USS North Carolina to Peru in November 1836 with a hastily assembled complement of seamen with pre-existing health problems, could place pressure upon the over-stretched personnel. ${ }^{17}$

Williamson's regulations attempted to provide a framework for the humane treatment of incapacitated servicemen. He elsewhere, in a series of reports to the secretary of the navy in 1840 , demonstrated a concern for the effective prevention of disease, through careful attention to personal hygiene, shipboard sanitation and the avoidance of a self-indulgent lifestyle. ${ }^{18}$ Williamson's negative view on the all-toofrequent human failings of the ordinary serviceman infused the regulations of 1838. In 1840 , for example, he argued strongly against the use of public monies to support the disabled seamen, "who by their excess in various ways, have brought about complicated and difficult [medical] states."

In 1838 his concern was for a well regulated, orderly environment for the care and nurture of incapacitated servicemen. The surgeon was identified as the key authority and agent for change in the institution, who possessed authority over both patients and hospital personnel. The emphasis upon the ability of the medical officers to control the institution, in contrast to a non-medical superintendent, arose out of the contests over jurisdiction as these new institutions were created. This mirrored the contemporaneous

Seaton, 1834-61), I: 616. See also the statistics for the years 1816 and 1817, when 98 and 162 new admissions respectively were made, Dr. George Kennon to the Secretary of the Navy, 29 May 1818, NARA, RG 45, Entry 464/205.

16 Quarterly reports, Norfolk Naval Hospital, NARA, RG 45, Entry 464/215. Many quarterly and annual reports for the 1830s are not extant in the National Archives.

17 Dr. William Smith to Mahlon Dickerson, 21 March 1837, and to James Paulding, 1 July 1839, NARA, RG 45, Entry 464/215.

18 Williamson to Paulding, 10 February 1840, NARA, RG 45, Entry 464/216. 
struggle at sea between medical and regular navy officers over the control of the servicemen and their sanitary environment. ${ }^{19}$

Dr. Thomas Williamson had the greatest influence of any individual upon the Norfolk Navy Hospital during the first quarter century of its existence. His regulations reflected his attitudes towards servicemen, medical hygiene, and the contemporary debate over the effective role of the medical officer in the anti-bellum Navy. They form an essential framework for studying the health care, society and politics within the new institutions. Hospitals - of many kinds - occupied an increasingly prominent place in early nineteenth-century America. As the first complete set of regulations established for the new permanent hospitals of the U.S. Navy, this document possesses pride of place and is deserving of notice and study.

\section{The Regulations}

Thomas Williamson to James K. Paulding

U.S. Naval Hospital, Norfolk, Virginia, 28 July $1838{ }^{20}$

In obedience to your direction I have the honor to lay before you such rules for the government of this Hospital, as seem to me called for. Viz:

$1^{\text {st }}$. The officers, and others, at the Hospital, should be as follows, Viz: one Surgeon, one Passed Assistant, ${ }^{21}$ and one young assistant, one Steward, two Cooks, two washers, four Nurses, four boatmen, two boys, for dispensary, and one porter, to be increased, or diminished, according to the number of sick, at the discretion of the Surgeon, approved by the Commanding Officer.

$2^{\text {nd }}$. The Steward, Nurses, attendents, and all others attached to the Hospital, are to be considered as belonging to the service, and as subject to the same rules and regulations that all are governed by. ${ }^{22}$

$3^{\text {rd }}$. No superintendent at the Hospital is to have any direction, or control, whatever, over the Medical officers, or those entrusted to their charge. ${ }^{23}$

19 For example, William P.C. Barton, Hints for Medical Officers Cruising in the West Indies (Philadelphia: Littel, 1830), passim.

20 NARA, RG 45, Entry 464/216 (“Epidemics, Reports on, 1830-40”). The author is grateful for permission to publish this document.

21 An assistant surgeon who had passed the surgeon's exam and was awaiting a vacancy for promotion to surgeon.

22 Barton, during his tenure as surgeon, had accused the hospital steward of corruption and had unsuccessfully attempted to discipline him, Holcomb, 172; Barton to [Branch], 15 November 1830, NARA, RG 45, Entry 464/205.

23 This clause was an early salvo in the long-running dispute at naval hospitals over the jurisdiction of the medical officers and the regular navy officers at each institution. According to clause 26 (below) the medical officers were under the immediate orders of the base's commanding officer, not of any subordinate authority. The superintendent was left with responsibility for the fabric of the institution, but with no control over the medical staff or patients. Williamson preferred to dispense with a non-medical superintendent altogether. 
$4^{\text {th }}$. No officer, or other inmate at the Hospital, or officers of the Navy, are to punish in any manner, persons who are in the charge of the Medical officers, but are to report to them, when those who are under their charge, are guilty of any offense.

$5^{\text {th }}$. All requisitions for articles required for the Hospital, are to be approved by the Commanding Naval officer. The medicines to be selected by the medical officers, and all articles carefully, and diligently to be examined, before they are receipted for by them.

$6^{\text {th }}$. No person to be received as a patient, at the Hospital, (except in cases of necessity) without the order of the Commanding officer of the station so that he may not be sent without a particular statement of his case, a list of his effects, and all other matters appertaining to him.

$7^{\text {th }}$ When a patient is received at, or discharged from, or dies, at the Hospital, the Commanding officer is to be informed of it in writing, so that the Hospital may be credited with the amount of substance according to the Law. ${ }^{24}$

$8^{\text {th }}$. The Medical officers at the Hospital are to be the sole judges of the necessity of receiving, or retaining, officers, or men, as Patients. ${ }^{25}$

$9^{\text {th }}$. Men are not to be received as Patients at the Hospital with slight affections, after being only three months shipped, as they might desert whilst in debt [to the state].

$10^{\text {th }}$. The sick, and everything appertaining to them, are exclusively in [the] charge of the Surgeon and his assistants. Therefore, their utmost attention is at all times required. $^{26}$

$11^{\text {th }}$. All directions from the Medical officers to the Patients under their charge, are to be strictly attended to. Any inattention to these matters will subject the persons so offending, to punishment at the discretion of the Surgeon.

$12^{\text {th }}$. All other offences committed by persons belonging to the service, and who are inmates at the Hospital, are to receive immediate and proper consideration, from the

In 1842 he wrote, "I am not aware that this hospital requires any superintendent other than a medical officer ... The Surgeon should ... be the only superintendent under the Bureau of Medicine and Surgery... It is not possible that we can ... permit any superintendent to take precedence of us [the medical officers] in regard to any comfort and convenience at Hospitals, where we are stationed. Are they to do just as they desire in everything pertaining to us." Quoted in Holcomb, 224.

24 Substance refers to subsistence, or the daily ration.

25 In 1830 Barton had complained that the new hospital was becoming merely a cheap boarding house for naval officers and midshipmen, who used "trifling complaints" to secure admission: Barton to [Branch] 15 November and 7 December 1830, NARA, RG 45, Entry 464/205.

26 Barton in 1830 had explicitly required that the assistant surgeon reside on the premises: Barton to [Branch], 15 November 1830, ibid.. In 1835 Dr. Bailey Washington recommended to the secretary of the navy against compulsory residence in my naval hospital for the surgeon-in-charge: Washington to Mahon Dickerson, 26 January 1835, in ibid., Entry 464/206. 
Medical officers.

$13^{\text {th }}$. No article is to be brought into, or carried out of, the Hospital, by Patients, or others, without the special permission of the Medical officers, otherwise, it will subject the offender, as in the previous article.

$14^{\text {th }}$. Officers, and men, (except in cases of accident) are only to be received at the Hospital in the afternoon, so as to prevent their drawing a ration previously to leaving the ship, and one again at the Hospital.

$15^{\text {th }}$. The sick are daily to be closely attended to by the Medical Corps. Always of a morning early, and late in the afternoon, and frequently in the day, and at night, so that, every attention, and comfort called for by the necessities of a Patient, may be duly looked to.

$16^{\text {th }}$. Every part of the Hospital is to be visited daily by a Medical officer, whose special duty it will be, to see that every part is kept clean - Wards dry, and well aired Beds, and bedding, clean, and frequently aired - Patients clean and well clothed. The provision for the sick, to be well cooked, and under the direction of the steward, to be properly distributed. And also, he should not allow under any consideration, the clothes of the Patients, in, and near, their beds. ${ }^{27}$ Their clothes aired frequently, and to be kept clean.

$17^{\text {th }}$. The Hospital is never to be left without a Medical officer, and no Patient, or nurse, is ever to leave it, without his special permission. Nor is admittance on business, or to visit the Patients, to be given, without his consent.

$18^{\text {th }}$. Visitors are only to be admitted by the Medical officers, or the Superintendent, under the direction of the Commanding Naval officer, and any insult to a visitor, by a Patient, or inmate, is instantly [to] be reported, and the offender sent out of the Hospital, at the discretion of the Surgeon and Commander.

$19^{\text {th }}$. Should any one belonging to the service be found injuring or defacing the building, trees or shrubbery, soiling the floors, or walls, by spitting, or otherwise, he is to be reported to the Commander, and with his approval to be made to pay for the same, or to be sent from the Hospital. If a citizen, his name is to be recorded in a book to be kept

27 It was believed that clothing could harbor miasmatic, airborne, diseases. 
for that purpose at the Hospital, and he is to be refused permission again to visit the establishment.

$20^{\text {th }}$. No smoking is allowed in any part of the Hospital building, or precincts, except that part of the basement story in the rear of the Court Yard, which will be pointed out by the Medical officers, or Superintendent. ${ }^{28}$

$21^{\text {st }}$. No boats are to be allowed to take water at the Hospital, as it is desirable that the establishment should be kept as quiet, and as private as practicable. Nor are the seamen permitted to ramble over the grounds, without special permission from the Medical officers, or Superintendent, under the directions of the Commanding Naval officer.

$22^{\text {nd }}$. All fires and lights are to be guarded with the greatest attention Extinguished at 9 P.M. in summer, and 8 P.M. in winter - Except such as are ordered, by the Medical officers for those who are very sick. The lights are always to be kept in lantherns, a regular watch [kept] by them, and duly reported to Medical officers.

$23^{\text {rd }}$. A quarterly return of the sick at the Hospital is to be forwarded to the Navy Department, a weekly report to be furnished to the Commanding Naval officer, and he is to be made acquainted with every suggestion in regard to health, and all matters relating

28 This limitation on smoking is the first restriction in practice to be uncovered for the U.S. Navy. The standard medical literature on Anglo-American armed forces, from Thomas Willis to James Lind, had supported tobacco smoking and burning as a preventative against miasmatic disease. Dr. Usher Parsons of the U.S. Navy was fully in agreement. Although British medical opinion began to change around 1800, in American popular lore (as, for example in Moby Dick) the old beliefs long lingered. The first medical officer of the U.S. Navy to speak out in print against tobacco consumption was, in fact, William Barton. In 1830 he condemned the "filthy and vulgar practices" of tobacco smoking and chewing and the taking of snuff, which - in his opinion - produced gastric uneasiness, nervous tremors, debility, and alcoholism. Dr. George Davis, one of the original U.S. Navy surgeons appointed in1799 and subsequently the American consul at Tripoli, banned smoking, except on medical orders, in his proposed regulations for U.S. Navy hospitals of March 1811 (for unspecified reasons), but these proposals were stillborn and soon forgotten. In 1814, Barton prohibited in-door smoking in his model hospital institution, also without comment. Williamson's reasons for imposing the limitation probably followed Barton's arguments of 1830, but may also have included the issues of hospital decorum (clause 19) and fire safety (clauses 22, 25). Thomas Willis, A Plain and Easie Method for ... the Plague; Or any Contagious Distemper in City, Camp, Fleet, etc. (London, 1691), 20-1; The Health of Seamen: Selections from the Works of Dr. James Lind, Sir Gilbert Blane and Dr. Thomas Trotter, Christopher Lloyd, ed. (London: Naval Records Society, 1965), 46, 101; James Lind, An Essay on Diseases Incidental to Europeans in Hot Climates, Benjamin Rush, ed. (Philadelphia, 1811), 101-3; Usher Parson, Sailor's Physician, 2nd ed. (Providence, 1824), 146-7; Thomas M. Winterbottom, Medical Directions for the Use of Navigators and Settlers in Hot Climates (London, 1803), 5; Herman Melville, Moby-Dick: Or, the Whale, L.S. Mansfield and H.P. Vincent, eds. (New York, 1962), 116; Barton, Hints for Medical Officers, 89; James Alsop, “Surgeon Davis's Regulations for U.S. Naval Hospitals (1811)," The Grog Ration 5, no. ii (March-April 2010), 6-10; Barton, Marine Hospitals, 103. 
to the sick.

$24^{\text {th }}$. The Medical Journal - The daily expenditures - The deaths, and burials The effects of deceased persons, and an inventory of their effects, are matters of so much importance, as to require at all times the greatest vigilance on the part of the Surgeon and Assistants - Care, and great neatness in the first, strict accountability in the second, Solemnity, and decorum in the third, and fourth, and in the last, unbending integrity.

$25^{\text {th }}$. A regular watch by the nurses and boatmen is to be kept at the Hospital, by night, so that the greatest attention may be give to Patients, and the public properly protected from fire, or other accidents.

$26^{\text {th }}$. All Medical officers, and others at the Hospital, are to be under the immediate orders of the Commanding Naval officer of the station.

By adopting the rules which I have suggested, and by unanimity of feeling and conduct on the part of those whose necessities compel them to be its inmates, we shall preserve it entire, and make it, as it should be, the abode of comfort, and the cause of honorable pride.

I would most respectfully call your attention to the importance of having at this Hospital, a young assistant surgeon, in addition to the valuable passed assistant (Dr. Mercer) who is now here. ${ }^{29}$ It would be a good school for him, previous to going on ship board, and he might be made very useful, when our sick list is large. You will at once see the importance of having the Steward, Nurses, attendants, etc. placed under naval regulations.

A well regulated Hospital should be allowed an officer similar to the one stated above ${ }^{30}$ or a careful apothecary. Also, a matron, whose duty it should be to look particularly to the internal arrangement of beds, and bedding, washing, cooking etc. ${ }^{31}$

29 John Mercer, passed assistant surgeon, on duty at Norfolk, 1835-38: Holcomb, 510.

30 The junior assistant surgeon. This recommendation was ignored and the establishment remained limited to one surgeon and one passed assistant surgeon.

31 In 1842 Williamson wrote to Barton, then head of the Bureau of Medicine and Surgery, again requesting the appointment of a hospital matron. The latter agreed in principle, but deferred the additional expenditure to a later date: Holcomb, 225. 


\title{
CNRS 2011 Conference and AGM
}

\section{Nautical Voyages}

\section{Cruising, Yachting and Small-boating Through the Ages}

\author{
Ottawa - 18-21 May 2011
}

\section{Call for Papers}

Whether for commerce, exploration, war fighting or simple pleasure cruising, travel on water - oceans, seas, lakes, rivers and canals - takes many forms and has been a staple of human transportation for at least as long as the wheel. Papers are invited to address any variety of perspectives on related themes involving ships, people, ports or trade. The Society reserves first right of refusal for publication in our journal The Northern Mariner / Le Marin du nord or newsletter Argonauta as appropriate, and new scholars are invited to apply for the Panting Bursary to support travel to deliver a paper (details on our web-site: www.cnrs-scrn.org).

Ottawa, the nation's capital, is strategically placed for this conference, located at the confluence of the Gatineau and Rideau with the Ottawa Rivers, and at the northern mouth of the UNESCO Heritage Site Rideau Canal. Mid-May also is the height of the Tulip Festival. Conference sessions and banquet will transpire in the historic quarters of HMCS Bytown, since 1943 the Wardroom (officers mess) for naval officers serving in the national defence headquarters, and there will be an optional evening dinner cruise on the Rideau Canal. A variety of accommodation options are available in the immediate area.

Paper proposals and administrative enquiries should be directed to:

Dr Richard Gimblett

CNRS 2011 Conference Coordinator

49 South Park Drive, Ottawa, Ontario, K1B 3B8

Telephone: 613-830-8633

email: richard.gimblett@rogers.com

Further details will be published as soon as they are available on our conference webpage at http://www.cnrs-scrn.org 